\title{
TOWARDS THE RECONCEPTUALISATION OF SOCIAL WELFARE IN SOUTH AFRICA: AN ANALYSIS OF RECENT POLICY TRENDS
}

\section{Mike Weyers}

\section{INTRODUCTION}

Nearly 20 years have elapsed since the heady days of South Africa's first democratic elections and the publication of the Reconstruction and Development Programme (RDP), the document that was intended to chart the country's future development (ANC, 1994:1). It was soon followed by the White Paper for Social Welfare, which would help "realise the relevant objectives" of the RDP through the use of developmental social welfare (MWPD, 1997:5,68). Developmental social work would constitute the profession's specific contribution to the developmental approach and, ultimately, to practice (Patel, 2005:206-210).

The developmental social welfare approach has remained the operational paradigm of the Department of Welfare and its successor, the current Department of Social Development (DSD), since 1997. As recently as October 2012 the DSD officially confirmed its commitment to the principles and practices espoused by the White Paper in the draft White Paper on Families (DSD, 2012b:7-13). This, invariably, also still officially links it, in principle, to the RDP.

However, on 15 August 2012 a new "roadmap" for South Africa, as President Jacob Zuma put it (Zuma, 2012), was tabled in Parliament by the Minister in the Presidency, Trevor Manual. This was the National Development Plan 2030 (NPC, 2012). This new plan would, for all practical purposes, be the replacement of the RDP, the Growth, Employment and Redistribution (GEAR) strategy and the National Growth Path (NGP) (Du Plessis, 2013; Laubscher, 2013).

The contents of the National Development Plan (NDP) immediately raised the question of whether developmental social welfare still is - and if so, would remain - the de facto approach in the South African social welfare field. In order to find an answer, a policy analysis study was conducted in which the contents of the NDP, as well as various other supportive and related publications, were analysed with the help of a newly developed typology. The article will focus on the nature of the research design, the typology used in the analysis and the findings of the study.

\section{RESEARCH AIM AND DESIGN}

The basic aim of the study was to determine the extent to which the developmental social welfare paradigm still remains the de facto approach in South African social welfare policy. It involved the use of a qualitative research design (Lammers \& Badia, 2005:265-266) and especially followed the guidelines that Gonçalves, Gomes, Alves and Azevedo (2012:275-288) set for the analysis of policy documents. This procedure entails the development of a structured conceptual tool or framework that would then be used to interrogate policy documents in order to expose recurrent themes. 
An initial document analysis indicated that a typology of the institutional and social development perspectives on the role and functions of social welfare in society would be the most appropriate conceptual framework to use. The background and nature of this typology will first be dealt with.

\section{TYPOLOGY USED IN THE POLICY ANALYSIS}

Social welfare may be seen as "A nation's system of programs, benefits, and services that help people meet those social, economic, educational, and health needs that are fundamental to the maintenance of society" (Zastrow, 2014:3). Its distinguishing feature (as opposed to commercial enterprise) is that the recipients of the benefits or services do not (fully) pay for the costs involved. The brunt of these costs is carried by the rest of society.

South Africa's social welfare policy should be seen against the backdrop of the different macro perspectives on the role and function of social welfare in society. The three most prominent perspectives, sometimes also conceptualised as approaches, views and perceptions, will be covered first. This will be followed by a typology in which the constituent modes of two of the perspectives are contrasted.

\section{Perspectives on the role and function of social welfare}

There are three dominant perspectives on the role and function of social welfare, viz. the residual, institutional and developmental. Both the residual and institutional perspectives and their accompanying approaches have a needs and social pathology focus.

In the case of the residual view, social welfare has a gap-filling or first-aid role and is intended to provide for an individual's needs only if these could not properly be met through other societal institutions, primarily the family and the market economy (Weyers, 2011:13; Zastrow, 2014:6). In its classic form, it entails "charity for unfortunates", where the provision of funds and services is seen not as a right but as a gift (Zastrow, 2014:6).

In the case of the institutional view, the point of departure is that there is "nothing wrong" with the consumer system (Weyers, 2011:13). Individuals' difficulties are due to causes largely beyond their control (e.g. by factors in their environment/ society) and, because of this, they are entitled to help from the state and the other institutions of a modern society (Weyers, 2011:13; Zastrow, 2014:6-7). This view often finds its ultimate expression in a constitution-based bill of rights that entrenches the state's liability to provide people in need with a social security safety net (e.g. Act 108 of 1996: Art. 27).

According to Weyers (2011:13), the developmental approach represents a somewhat different view. He states that, whereas the other approaches basically see the expenditure of time, money and effort on social services as an unavoidable (residual) or morally justifiable (institutional) "loss item" in a country's "balance sheet", this approach is predicated on the idea that appropriately designed and implemented programmes would actually enhance its economic development. There are, however, divergent views on the types of programmes and interventions that this would require. Kirst-Ashman (2007:10), for example, expresses the view that expenditure on macro social services such as education, nutrition and health care would "turn a profit" by producing a more skilled and healthy workforce that in turn 
would generate a stronger economy. On a more micro level, Midgley and Conley (2010:xiii-xiv) and Theron $(2008: 13,15)$ are of the opinion that social investment in microenterprise, job training, employment placement, adult literacy and other participatory capacity-building programmes would either "lift" people out of poverty or prevent them from becoming dependent on the rest of society. The common denominator in these authors' views, as well as those of numerous others, are arguably best summarised by Estes (1998:2), who states that the proposed interventions are all aimed at "helping people to realize the fullness of the social, political, and economic potentials that already exist within them" (original emphasis).

The utilisation of the developmental approach to social welfare in South Africa was first implied in the RDP (RDP, 1994:9,27,42) and later entrenched in the White Paper on Social Welfare (MWPD, 1997:5). Neither source provided a clear definition of the meaning of the construct "developmental social welfare" within their specific contexts. This gave rise to years of debate and a diversity of interpretations of the attributes that should be allocated to the construct (Lombard, 2008:158). This is predominantly still the case.

\section{Typology of the institutional and developmental perspectives}

Although all three macro perspectives were originally covered by the study, it soon became apparent that the residual view plays only a minor role in current South African welfare policy. Owing to length constraints, findings in this regard will not be covered in the typology.

Any attempt to develop a typology of diversely formulated and often vague constructs is hazardous. Researchers could easily be accused (and convicted) of quoting different authors' views out of context, of attributing meanings to texts that were never intended or of being biased in the selection of only specific opinions. It is especially true in this case because of the fact that neither the institutional nor the social development perspectives represent a unified view or body of knowledge. The newly developed typology (Table 1) should therefore be seen as only one way in which a diversity of views on the nature of the two perspectives could be structured.

The typology is based on a conceptual framework that was originally developed by Richard Estes (1998:8-11). His framework has been adapted and expanded to accommodate other and newer publications in the fields of social welfare, social work and social development. The resultant typology is structured according to two sets of criteria. The first covers the variables most often used in the demarcation of social theories, approaches and practice models. It includes the assumptions on which they are based, the goals they strive to attain, the typical strategies that would be followed and the modes of practice that will be used (Estes, 1998; Rothman, 1995; Sheafor, Horejsi \& Horejsi, 1997; Weyers, 2011). Ten of the most commonly used variables have been selected for the typology (Estes, 1998:8-11). The second set comprises the two selected perspectives.

To facilitate the later use of the typology in the analysis of policies and trends, the ten variables, as well as their "manifestations" in each of the perspectives, have been numbered. The manifestations, which will be typified as "modes" (i.e. the ways or 
manner in which something occurs or is experienced, expressed or done), will be grouped according to the institutional perspective (abbreviated as "IP") and the social development perspective (abbreviated as "SDP") (Table 1).

\section{TABLE 1}

\section{TYPOLOGY OF THE INSTITUTIONAL AND SOCIAL DEVELOPMENT PERSPECTIVES ON SOCIAL WELFARE}

\begin{tabular}{|c|c|c|}
\hline VARIABLES & $\begin{array}{l}\text { THE INSTITUTIONAL } \\
\text { PERSPECTIVE (IP) } \\
\end{array}$ & $\begin{array}{l}\text { THE SOCIAL DEVELOPMENT } \\
\text { PERSPECTIVE (SDP) } \\
\end{array}$ \\
\hline Basic vision & $\begin{array}{l}\text { IP1: The elimination of individual and } \\
\text { societal dysfunction. }\end{array}$ & $\begin{array}{l}\text { SDP1: The elimination of poverty and } \\
\text { inequality. }\end{array}$ \\
\hline $\begin{array}{l}\text { Basic } \\
\text { assumptions } \\
\text { regarding the } \\
\text { human } \\
\text { condition }\end{array}$ & $\begin{array}{l}\text { IP2.1: Social dysfunction is inherent in } \\
\text { the human condition, but can be } \\
\text { rectified through appropriate services. } \\
\text { IP2.2: Some groups of people - as a } \\
\text { result of factors largely beyond their } \\
\text { control - are disadvantaged by } \\
\text { stratification norms that reward some, } \\
\text { but penalise many. } \\
\text { IP2.3: Social dysfunction occurs: } \\
\text { - because at various times in their lives } \\
\text { some people require short-term } \\
\text { assistance in coping with problems } \\
\text { of daily living (e.g. family } \\
\text { dysfunction, income insecurity, } \\
\text { serious illness, disability, etc.); and } \\
\text { - because some members of society } \\
\text { are unable to function independently } \\
\text { and require more intensive assistance } \\
\text { over the longer term. }\end{array}$ & $\begin{array}{l}\text { SDP2.1: Current levels of human misery, } \\
\text { degradation and interpersonal conflict are } \\
\text { unnecessary. } \\
\text { SDP2.2: Some groups of people - as a } \\
\text { result of factors largely beyond their } \\
\text { control - are disenfranchised by a } \\
\text { political-economic system that promotes } \\
\text { economic growth at the cost of social } \\
\text { justice for all. } \\
\text { SDP2.3: Persistent social, political and } \\
\text { economic inequalities in developing } \\
\text { countries result from: } \\
\text { - a legacy of colonialism or past } \\
\text { injustices; } \\
\text { - internal corruption, inefficiencies and } \\
\text { an entrenched system of inequality; and } \\
\text { - "accidents" of geography and history } \\
\text { that trap poor countries in conditions of } \\
\text { perpetual deprivation. }\end{array}$ \\
\hline $\begin{array}{l}\text { Characteristic } \\
\text { macro policy } \\
\text { approach }\end{array}$ & $\begin{array}{l}\text { IP3.1: A two-step approach that } \\
\text { consists of: } \\
\text { IP3.1.1: the creation of a robust } \\
\text { (capitalist) economy and (individualist) } \\
\text { society that utilises the "products" of } \\
\text { both; } \\
\text { IP3.1.2: the creation of (government } \\
\text { supported) social support programmes } \\
\text { and services for those individuals who } \\
\text { might need or benefit from them at } \\
\text { some stage in their lives. }\end{array}$ & $\begin{array}{l}\text { SDP3.1: A two-pronged approach } \\
\text { consisting of: } \\
\text { SDP3.1.1: the changing of macro socio- } \\
\text { economic and political policies; plus } \\
\text { SDP3.1.2: investment in participatory } \\
\text { social development initiatives, especially } \\
\text { at the mezzo level. }\end{array}$ \\
\hline $\begin{array}{l}\text { Characteristic } \\
\text { social welfare } \\
\text { goals }\end{array}$ & $\begin{array}{l}\text { IP4.1: To extend to people everywhere } \\
\text { a range of social and support services } \\
\text { that are needed to restore, enhance and } \\
\text { protect their capacity for social } \\
\text { functioning. The services should } \\
\text { function as a safety net and include: } \\
\text { - remedial and preventive services } \\
\text { delivered to people whose optimal } \\
\text { social functioning has been impaired } \\
\text { or interrupted; } \\
\text { - social protection services delivered } \\
\text { to groups threatened by exploitation } \\
\text { or degradation; } \\
\text { - a social security system that protects } \\
\text { individuals and groups in need; and }\end{array}$ & $\begin{array}{l}\text { SDP4.1: To create a more equitable and } \\
\text { just society, especially through: } \\
\text { - the redistribution of power and material } \\
\text { resources; and } \\
\text { - the elimination of barriers to } \\
\text { development. } \\
\text { SDP4.2: To promote the fullest possible } \\
\text { participation of people in their own social } \\
\text { development. } \\
\text { SDP4.3: To promote internationally } \\
\text { guaranteed human rights. }\end{array}$ \\
\hline
\end{tabular}




\begin{tabular}{|c|c|c|}
\hline VARIABLES & $\begin{array}{l}\text { THE INSTITUTIONAL } \\
\text { PERSPECTIVE (IP) } \\
\end{array}$ & $\begin{array}{l}\text { THE SOCIAL DEVELOPMENT } \\
\text { PERSPECTIVE (SDP) } \\
\end{array}$ \\
\hline & $\begin{array}{l}\text { - empowerment services intended to } \\
\text { foster self-help, mutual aid and a } \\
\text { more humane society. } \\
\text { IP4.2: To promote internationally } \\
\text { guaranteed human rights. }\end{array}$ & \\
\hline $\begin{array}{l}\text { Basic } \\
\text { assumptions } \\
\text { regarding the } \\
\text { function of } \\
\text { social welfare }\end{array}$ & $\begin{array}{l}\text { IP5.1: Social welfare is the primary } \\
\text { mechanism through which societies } \\
\text { respond to the legitimate psychosocial } \\
\text { and, through the creation of a safety } \\
\text { net, also the economic needs of } \\
\text { population groups at risk. This view } \\
\text { finds it ultimate expression in the } \\
\text { welfare state system. } \\
\text { IP5.2: Services are able to restore or } \\
\text { enhance the social functioning of } \\
\text { people to an optimal level of self- } \\
\text { sufficiency. } \\
\text { IP5.3: Social service professionals } \\
\text { (including social workers) possess a } \\
\text { unique body of knowledge and skills } \\
\text { that may be used to help people } \\
\text { eliminate or cope with a wide variety of } \\
\text { social problems. }\end{array}$ & $\begin{array}{l}\text { SDP5.1: Social welfare is the primary } \\
\text { mechanism through which a more } \\
\text { equitable distribution of wealth among the } \\
\text { citizenry of a country can be achieved. } \\
\text { SDP5.2: Services are able to empower } \\
\text { people to become part of, and contribute } \\
\text { to, the socio-political-economic } \\
\text { development of a country. } \\
\text { SDP5.3: Social development specialists } \\
\text { (including social workers) possess a } \\
\text { unique body of knowledge and skills that } \\
\text { can be used to find sustainable solutions to } \\
\text { recurrent socio-economic problems. }\end{array}$ \\
\hline $\begin{array}{l}\text { Characteristic } \\
\text { target systems }\end{array}$ & $\begin{array}{l}\text { IP6.1: Macro level: Target the power } \\
\text { elite in order to ensure that an effective } \\
\text { and efficient welfare services system is } \\
\text { created and maintained. } \\
\text { IP6.2: Mezzo level: Target } \\
\text { - the community and especially its } \\
\text { contribution to the social and } \\
\text { economic wellbeing of its constituent } \\
\text { individuals and family groups; and } \\
\text { - the organisational and service } \\
\text { delivery system found in, or missing } \\
\text { from, the community or region. } \\
\text { IP6.3: Micro level: Target vulnerable } \\
\text { individuals, families and small groups. }\end{array}$ & $\begin{array}{l}\text { SDP6.1: Macro level: Target the power } \\
\text { elite in order to ensure that a country's } \\
\text { economic and social development would } \\
\text { be harmonised. } \\
\text { SDP6.2: Mezzo level: Target } \\
\text { - groups, formal and informal organi- } \\
\text { sations (including people's movements } \\
\text { and self-help groups), communities, } \\
\text { sub-regions and nations; and } \\
\text { - local political and economic power } \\
\text { structures. } \\
\text { SDP6.3: Micro level: Target individuals } \\
\text { for empowerment through, for instance, } \\
\text { job training, employment placement and } \\
\text { adult literacy promotion. }\end{array}$ \\
\hline $\begin{array}{l}\text { Characteristic } \\
\text { change } \\
\text { strategies }\end{array}$ & $\begin{array}{l}\text { IP7.1: Lobbying the power elite to } \\
\text { provide: } \\
\text { - various forms of psychosocial } \\
\text { treatment and rehabilitation services; } \\
\text { - financial assistance and other } \\
\text { economic support services to the } \\
\text { poor based on eligibility and } \\
\text { established need; and } \\
\text { - assured access to at least basic } \\
\text { health, education and other essential } \\
\text { social services. } \\
\text { IP7.2: The utilisation of, among other } \\
\text { things, a broad range of social case- } \\
\text { work, group work and community work } \\
\text { techniques. }\end{array}$ & $\begin{array}{l}\text { SDP7.1: Pressurising the power elite into } \\
\text { the creation of a more just society. } \\
\text { SDP7.2: The utilisation of a broad range } \\
\text { of group and community-building } \\
\text { techniques including conscientisation } \\
\text { (social animation), self-help promotion, } \\
\text { mutual aid, entrepreneurship building, } \\
\text { income generation, conflict resolution, } \\
\text { institution building, etc. }\end{array}$ \\
\hline $\begin{array}{l}\text { Primary } \\
\text { agents of } \\
\text { social change }\end{array}$ & $\begin{array}{l}\text { IP8.1: Public and private welfare } \\
\text { institutions. } \\
\text { IP8.2: Interdisciplinary teams of human }\end{array}$ & $\begin{array}{l}\text { SDP8.1: People and governments colla- } \\
\text { borating in creating a new or improved } \\
\text { social dispensation. }\end{array}$ \\
\hline
\end{tabular}




\begin{tabular}{|l|l|l|}
\hline VARIABLES & $\begin{array}{l}\text { THE INSTITUTIONAL } \\
\text { PERSPECTIVE (IP) }\end{array}$ & $\begin{array}{l}\text { THE SOCIAL DEVELOPMENT } \\
\text { PERSPECTIVE (SDP) }\end{array}$ \\
\hline $\begin{array}{l}\text { pervice professionals and } \\
\text { private human service organisations. }\end{array}$ & $\begin{array}{l}\text { SDP8.2: Teams of trained professionals } \\
\text { and multidisciplinary development experts } \\
\text { in cooperation with governmental entities, } \\
\text { people's organisations and other } \\
\text { collectives. }\end{array}$ \\
\hline $\begin{array}{l}\text { Primary } \\
\text { domain of } \\
\text { practice }\end{array}$ & IP9.1: Social welfare and social work. & $\begin{array}{l}\text { SDP9.1: As yet still undifferentiated and } \\
\text { broad (may range from agriculture to } \\
\text { economic development and income } \\
\text { generation, and from rural and urban } \\
\text { development to social welfare) }\end{array}$ \\
\hline $\begin{array}{l}\text { Pressures for } \\
\text { initiatives }\end{array}$ & $\begin{array}{l}\text { IP10.1: Deteriorating socio-economic } \\
\text { conditions in countries that threaten the } \\
\text { social functioning or economic security } \\
\text { of its disadvantaged population groups. } \\
\text { IP10.2: Increasing numbers of } \\
\text { "dysfunctional" or socio-economically } \\
\text { dependent people who need assistance. } \\
\text { IP10.3: Social conflicts arising from a } \\
\text { growing “underclass" of people who } \\
\text { are unabble to participate meaningfully } \\
\text { in the existing social order. }\end{array}$ & $\begin{array}{l}\text { SDP10.1: International and national } \\
\text { pressures to respond more equitably to the } \\
\text { legitimate needs and rights of } \\
\text { disenfranchised populations. } \\
\text { sDP10.2: The need for the social } \\
\text { "animation" of previously oppressed or } \\
\text { disadvantaged peoples. } \\
\text { SDP10.3: Recurrent global crises (e.g. } \\
\text { economic downturns) that tend to have the } \\
\text { most devastating effects on themost } \\
\text { vulnerable members of a society. }\end{array}$ \\
\hline
\end{tabular}

Within the South African context, the two perspectives or approaches (Table 1) represent analytically separable "routes" that could be followed to achieve the same common vision. This vision is arguably best articulated in the preamble of the White Paper for Social Development as:

"a humane, peaceful, just and caring society which will uphold welfare rights, facilitate the meeting of basic human needs, release people's creative energies, help them achieve their aspirations, build human capacity and self-reliance, and participate fully in all spheres of social, economic and political life" (DWPD, 1997:i).

The latest attempts to map the route to be followed in achieving this vision will be reviewed next.

\section{CONTEXTUALISING RECENT POLICY TRENDS: THE NATIONAL DEVELOPMENT PLAN AND ASSOCIATED DOCUMENTS}

Because of length constraints, it would not be possible to cover the NDP (a document of more than 480 pages) in any detail. At this stage the aim is only to provide an overview of those elements of the plan that would contextualise the new directions in welfare policy. This overview will be augmented with some of the ideas and data that emerged from the 2013 Budget and related documents. A more detailed analysis of policy trends will follow in the final content section of this article.

\section{An overview of the National Development Plan 2030}

The NDP represents the new "roadmap" to be followed to achieve two clearly stated overarching goals, namely "to eliminate poverty and reduce inequality by 2030" (NPC, 2012:24,354). This would imply, in concrete terms, that the proportion of South African households with a monthly income of below R419 per person (the absolute poverty line 
in 2009 prices) would have to be reduced from the current 39\% to zero and that the Gini Coefficient (i.e. the standard economic measure of income inequality) should fall from 0.69 to 0.6 by 2030 (NPC, 2012:36).

In the foreword to the NDP the chairman of the National Planning Commission (henceforth the NPC or the Commission) and its main author, Trevor Manual, describes the document as follows:

"The plan addresses the need to enhance the capabilities of our people so that they can live the lives that they desire; and to develop the capabilities of the country so that we can grow faster, draw more people into work and raise living standards for all, but particularly the poor. This is a plan for South Africa, requiring action, change and sacrifice from all sectors of society" (NPC, 2012:1).

The NDP is, to a large degree, a response to the findings contained in the National Planning Commission's 2011 Diagnostic Report (NPC, 2012:25). This report frankly and honestly highlights a number of socio-economic and political problems faced by the country and comes to the conclusion that "Eliminating poverty and reducing inequality will require bold actions" and will involve building "a national consensus on the right way forward for South Africa” (NPC, 2011:2,40). The NDP would, by implication, provide the required:

- basis for the building of national consensus;

- framework for the consolidation of the current, somewhat fragmented, anti-poverty policy; and

- planning instrument to be used in addressing poverty and inequality (May, 2004:13; NPC, 2012:20-38).

The government has already taken a number of steps to entrench the NDP as a consensus-building, policy-consolidation and planning tool. It includes the requirement that future budgets and policies should be aligned with its provisions (NT, 2013a:iii). This implies that the NDP has ostensibly replaced previous policy guidelines such as the RDP and GEAR.

The Commission used the diagram in Figure 1 to summarise their "capabilities approach" to change (NPC, 2012:38). These "capabilities" (Figure 1) refer to the education, skills and opportunities that individuals would require to "live the life that they desire", as well as the capabilities of the state to create the conditions and opportunities in which this can occur (NPC, 2012:26-27,38). It will require an effective government, strong leadership in all sectors of society and an active citizenry (NPC, 2012:1,26-27). 
FIGURE 1

\section{SUMMARY OF THE APPROACH TO CHANGE AS ESPOUSED IN THE NDP}

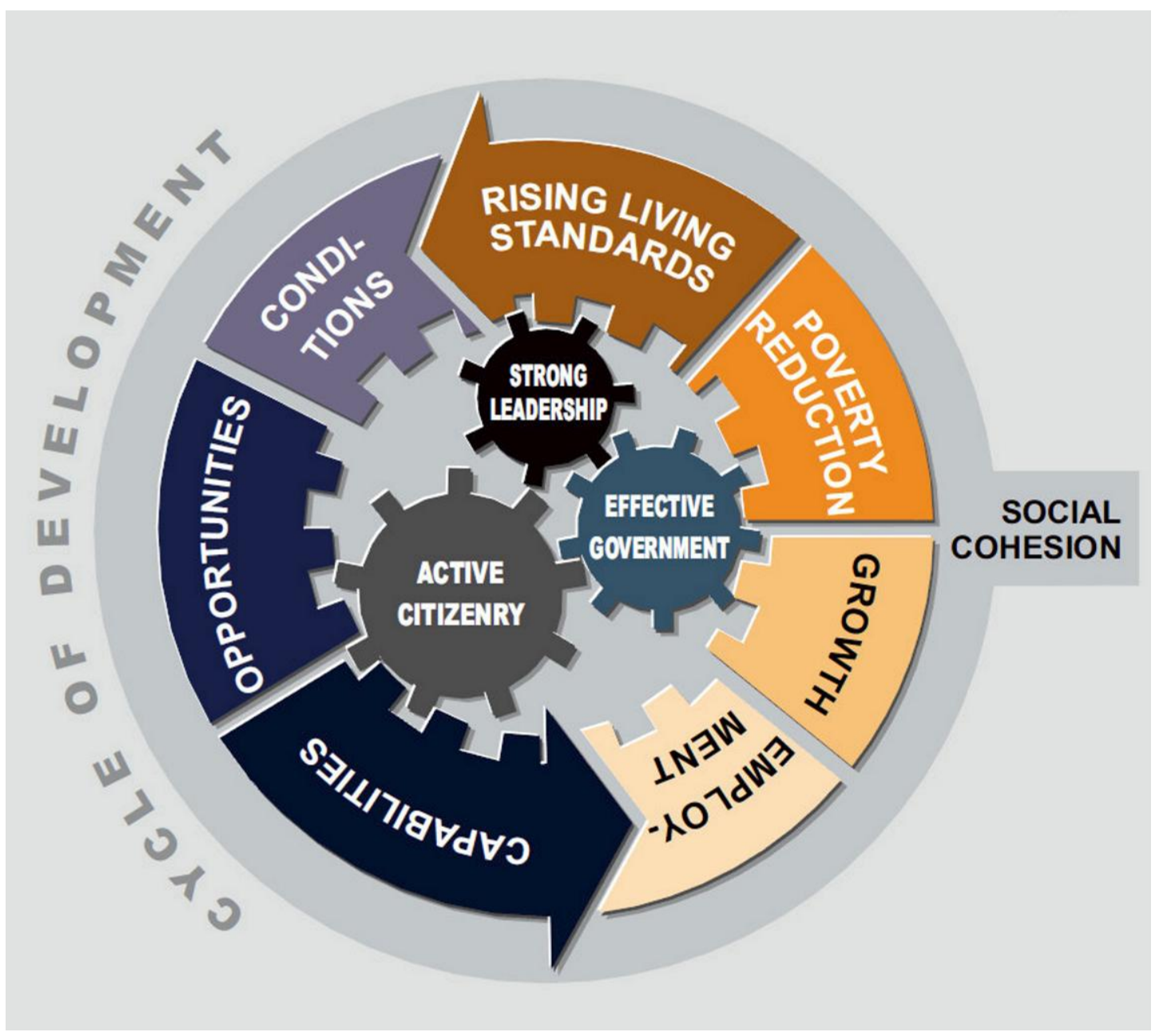

Derived from NPC (2012:26).

The NPC contains more than 70 objectives and specifies a total of 119 actions that would be necessary to bring about the required change (NPC, 2012:61-73). They involve nearly every sector of South Africa's socio-economic and political life. One of these sectors is social protection.

\section{The National Development Plan's stance on social protection}

The Commission describes its approach to social protection as being different from "the typical Western industrial model" and states that it is "based on a hybrid model that protects the vulnerable and those at risk while at the same time ensuring economic inclusion through a range of active strategies" (NPC, 2012:355). The "range of strategies" mainly entails the promotion of economic and job growth coupled with services that would build the "capabilities" of individuals to take part in the formal economy (NPC, 2012:354). The hybrid model's focus on "capability building" and job creation, on the one hand, and ensuring that no one lives below a defined minimum "social floor" (NPC, 2012:355), on the other, runs throughout the chapter and most of the document. Social protection is placed squarely in the latter category. 
The NPC is of the opinion that South African social protection should be protective, preventive, promotive, transformative and developmental (NPC, 2012:355). The promotive, transformative and developmental functions seem, at first glance, to contradict the traditional view that the protection should only apply to the "critically poor" (World Bank, 2001:9). It is only when the NPC goes on to explain that it conceptualises social protection more broadly (NPC, 2012:357) that its interpretation becomes clearer. It covers all steps necessary to address the country's apartheid legacy and includes reducing the cost of living for low-income and working-class households (especially the cost of food, energy and transport), redistributing wealth and stimulating the economy of especially rural areas (NPC, 2012:116,198,283).

\section{The 2013 National Budget and the cost of the "social wage"}

The 2013 Budget Review states that it is "the first budget in which Government's plans to implement the National Development Plan (NDP) are beginning to take shape", that government departments "will increasingly align their planning and expenditure to meet the objectives of the NDP" (NT, 2013a:iii) and that strengthening the social wage represents one of the "critical actions" required by the NDP to promote growth and development (NT, 2013a:3). It may be deduced from these statements that an analysis of the 2013 budget would give some indication of how the NDP would be financed and operationalised in practice.

Although the Budget Review contains a number of references to the construct "social wage", it is only somewhat vaguely defined as the "Social benefits available to all individuals, funded wholly or partly by the state" (NT, 2013a:212). The same vagueness is found in the NDP, where it is defined as the "amenities provided to society through public funds" (NPC, 2012:61).

From an analysis of the two documents it was deduced that the government ascribes to the so-called "broad definition" of the social wage as reflected in, among other things, the Encyclopaedia of Political Economy (O'Hara, 2001). In terms of this broad definition, the social wage entails government expenditure that affects living standards through both direct income transfers and the provision of services that are intended to guarantee that all citizens or families have an income sufficient to live on (Hyman, 2001:582; Rankin, 1996:1-2). In a broad sense this type of social wage would comprise:

- income replacements for those unable to be employed in paid work (e.g. old age grants);

- money income supplements (e.g. child support grants);

- subsidies or goods targeted to those on low incomes and tied to particular expenses (e.g. food and housing subsidies); and

- the provision of free or subsidised services (e.g. health care, education and public transport) (Hyman, 2001:582; May, 2004:7,12). 
The reverse side of the social wage would be the so-called "economic wage" (Gordhan, 2013:16). This entails citizens' income earned through work, profits and interest (Rankin, 1996:1).

To do a costing of the social wage, the data contained in the NDP (NPC, 2012) and Budget Review (NT, 2013a) were combined with other government publications such as the People's Guide: Budget 2013 (NT \& SARS, 2013) and Budget Vote 19: Department of Social Development (NT, 2013b). The resulting profile of estimated expenditure for the financial year 2013/2014 is contained in Figure 2.

\section{FIGURE 2}

\section{PROFILE OF ESTIMATED TOTAL EXPENDITURE: 2013/ 2014 BUDGET}

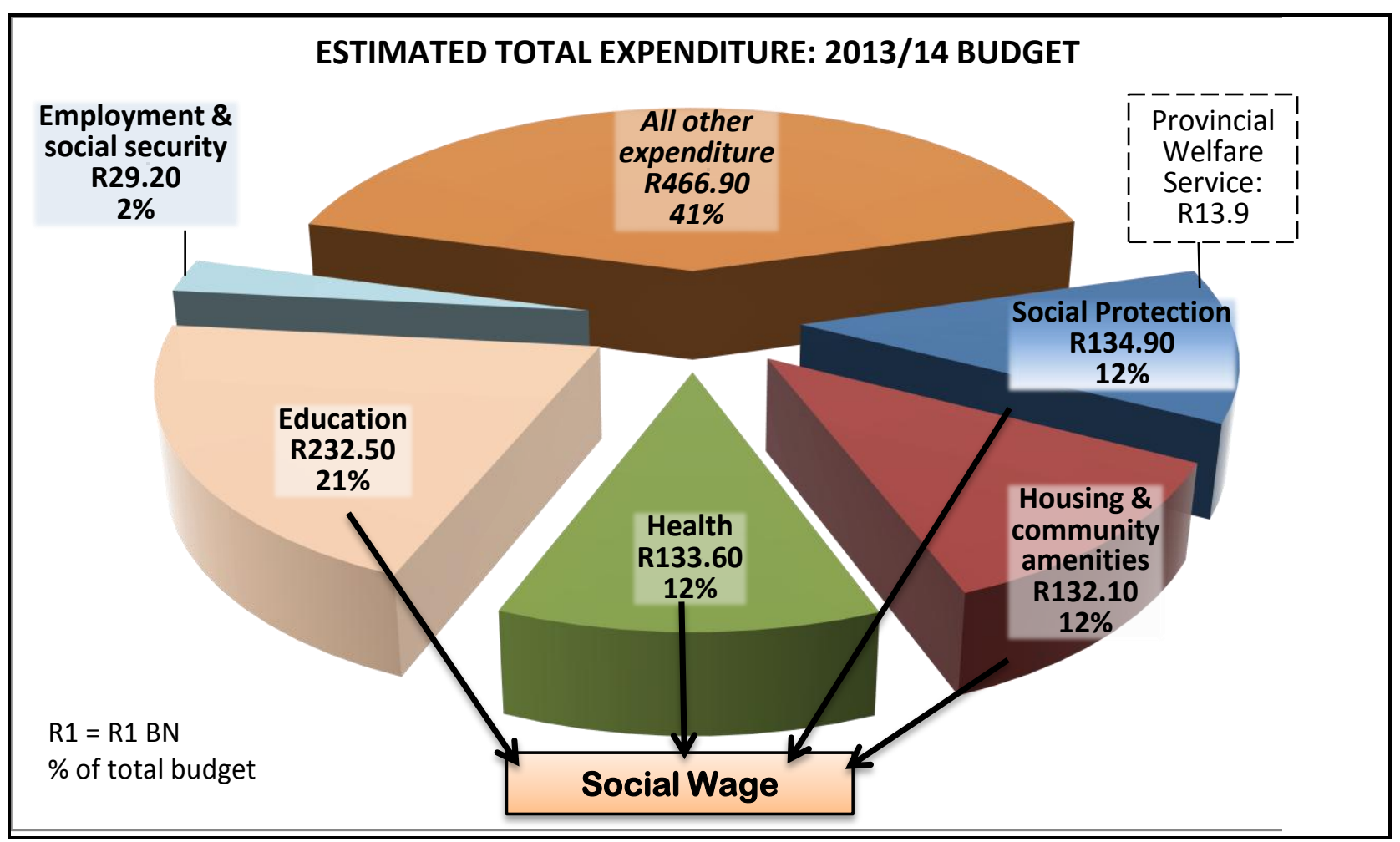

Main sources: DSD (2012a:18-21); NT (2013a:82-93); NT (2013b:82-94); NT \& SARS (2013:3)

The following important facts and trends emerged from the data on which Figure 2 is based.

- Approximately $57 \%$ of government spending in 2013/14 will be allocated to the social wage. This represents $19 \%$ of current GDP and is in real terms $3 \%$ more than in the 2002/03 budget (NT, 2013b:83).

- Social grants as a form of social protection are regarded as the government's most direct means of combating poverty.

- This component represents $93.8 \%$ of the DSD's total 2013/14 budget and is expected to grow to $94.1 \%$ in $2015 / 16$ (NT, 2013b:1).

- By the end of 2012/13, nearly 16.1 million people were beneficiaries of social grants, up from 2.5 million in 1998 (NT, 2013a:81). More than 50\% of all South 
African households benefit in some way from social assistance and for $22 \%$ the grants are their main source of income.

- The grants are funded directly through the fiscus and will contribute R113 billion to the income of low-income households in 2013/14 (NT, 2013a:84).

- In 2012/13 the child support grant was the largest programme by number of beneficiaries (11.4 million) and the old age grant the largest by expenditure (R40.5 billion) (NT, 2013a:122).

- According to the Diagnostic Report (NPC, 2011:21), the proportion of people who live below the poverty line has dropped from $53 \%$ in 1995 to $48 \%$ in 2008 . In the NDP (NPC, 2012:34, 118) the proportion for 2009 is, however, given as 39\%, while other estimates range from $23 \%$ to $57 \%$ (e.g. Index Mundi, 2013; Oosthuizen, 2008:12; World Bank, 2011). (The discrepancies are probably the result of different formulae used in the calculations).

- National and provincial social development departments transferred R5 billion to the non-governmental sector (NGOs) for welfare services in 2012/13 and this will increase to R6.5 billion in 2015/16 (NT, 2013a:86). An additional R600 million was allocated in 2013/14 to NGOs to offset reductions in donor funding (NT, 2013a:112,122).

- To strengthen provincial social welfare services, R938 million was allocated over the medium term to absorb social work graduates (NT, 2013a:112,122). Up to 2013 the Social Worker Scholarships programme had produced 6,082 new social workers, of whom 1,247 still had to be absorbed (PMG, 2013a).

- The social wage also covers a number of other programmes, which include the following:

- In 2011/12 the national school nutrition programme provided a daily meal to 8,850,208 learners at primary schools at a cost of R4.58 billion (NT, 2013a:89);

- The total cost of the expanded public works programme as administered by the Department of Public Works will be R1,95 billion in 2013/14 (NT, 2013a:120). The DSD's contribution to this programme entails, among other things, the recruitment of unemployed community members to assist with early childhood development and home- and community-based care (NT, 2013b:86);

- Households earning less than R3,500 per month qualify for a housing subsidy currently worth R84,000 (NT, 2013a:82).

If taken as a whole, it is clear that the social wage represents a massive and also a growing investment by government in a system that has all the features of a welfare state (Esping-Andersen, 1990; Mail \& Guardian, 2010). This trend could have serious implications for policy and practice.

\section{The national Department of Social Development (DSD)}

Owing to length constraints, it would not be possible to report in detail on all the policy trends that emerged from the analysis of, among others, the DSD's Annual Report 
(DSD, 2012a) and the 2013 Budget Vote (NT, 2013b:89), as well as the minutes of the meeting of the Parliamentary Committee on Social Development with the DSD on its Strategic Plan 2013 (PMG, 2013b). The focus would rather be on two trends that are linked more directly to the scope of the study.

The first trend that emerged was that some of the DSD's policies are already being aligned with the guidelines and recommendations contained in the NDP. One example (among many) is its response to the Commission's call for retirement reform (NPC, 2012:53,369). In this regard, the DSD had submitting a Consolidated Government Document on Social Security and Retirement Reform to cabinet which contained a number of proposals for the introduction of a mandatory retirement system and the establishment of a single Department of Social Security (DSD, 2012a:7).

The analysis secondly revealed that some important changes to the DSD's conceptualisation of the nature of community development and associated service delivery mechanisms are imminent. It includes changes to the functions of the National Development Agency (NDA). The DSD's Budget Vote (NT, 2013b:28,30) states that the NDA's "mandate is being reviewed, as it has been acknowledged that it is not sufficiently focused" and that it is projected that the Agency would spend R5.6 million "on consultants who will develop a system to help the agency devise a new strategic focus to fulfil its capacity-building role". The Budget Vote, however, also reveals that the NDA's 2013/14 funding allocation has already been reduced by R12 million (NT, 2013b:23). These trends are opposed to the fact that the Agency was originally touted as the mechanism through which participatory social development would be promoted in South Africa (Noyoo, 2006:25-26).

\section{AN ANALYSIS OF RECENT POLICY TRENDS}

In the study the typology of the institutional and social development perspectives on social welfare (Table 1) was used as a framework to analyse the policy trends that emerged from the NDP and related documents. One of the primary issues that had to be dealt with in this process was the inconsistent meanings that were attached to the same descriptors within and between the different policy documents. This links to Julian May's finding that the debate on the impact of South Africa's poverty strategy "has been made more complex by the loose fashion in which the terms social security, social protection, social assistance, safety nets and the social wage have been used" (May, 2004:6). Some of the other challenges were to distinguish between rhetoric/ "sloganizing" and substantive policy, as well as to find commonalities in the dissimilar meanings that are attached to the same constructs and contents in the different documents and even sometimes within the same document.

The analysis will utilise the variables contained in the typology (Table 1) as its primary organising principle. It will include references to the institutional [IP] and social development [SDP] modes as specified in the table. 


\section{Variable 1: Basic vision}

The vision expressed in the NDP and echoed in the 2013 Budget is overtly that of a social development approach, viz. the elimination of poverty and inequality (NPC, 2012:116,198,283) [SDP1]. This vision is even concretised by setting specific 2030 targets for the elimination of poverty and the reduction of inequality.

At a macro level the stated vision does not deviate in principle from the current (official) development-centred policy [SDP1], but rather re-emphasises it. The question, however, is to what extent the substance of the policy has remained the same. The answer would emerge from an analysis of the different components that make up the overall policy.

\section{Variable 2: Assumptions regarding the human condition}

The Commission was adamant that current unacceptable levels of poverty and inequality should be attributed to the legacy of apartheid (NPC, 2012:1,24,35,44,132) [SDP2.3]. The possibility that some groups of people may still be disenfranchised by the politicaleconomic system [SDP2.2] was not explicitly acknowledged. The continuation of the situation is rather blamed on, among other things, poor economic and job growth (in especially rural areas and for young people) [SDP2.2], corruption [SDP2.3] and inefficiencies in services, including education and welfare (NPC, 2012:116,198,283) [SDP2.3]. The fact that some people would require short- and long-term assistance [IP2.3] was acknowledged and seen as one of the reasons why improvements to the social welfare system are required.

An analysis of the basic assumptions on which the NDP is based indicates a strong social development orientation. The Commission saw structural-factional deficiencies [SDP2.1 \& SDP2.2] and not social dysfunction [IP2.1] as the primary cause of current levels of human misery.

\section{Variable 3: Macro policy approach}

The primary policy documents did not articulate a single or unified macro policy approach. The NDP described its "capabilities approach" as one aimed at enhancing the capability of the state to create conditions and opportunities that will enable individuals to better utilise their own capabilities "to live the life that they desire" (NPC, 2012:2627,38). When they translated the approach into priorities, it entailed, "Raising employment through faster economic growth. Improving the quality of education, skills development and innovation. Building the capability of the state to play a developmental, transformative role" (NPC, 2012:27). In the 2013 Budget the priorities expressed in the NDP were then somewhat reinterpreted and converted to "central priorities of public policy" (NT, 2013a:iii). These priorities entailed "eliminating poverty and reducing inequality, with a focus on lowering the costs of living and doing business, increasing exports, creating more jobs and making economic growth more inclusive" (NT, 2013a:iii).

From the available documents it may be deduced that, instead of the typical two-step approach of the institutional perspective or the two-pronged approach of social development (Table 1), a three-pronged macro approach is at play. These are the 
promotion of economic and job growth (i.e. the creation of conditions and opportunities), the improvement of the capabilities of individuals to participate in the formal economy (i.e. "capacitating") and the protection of the most vulnerable citizens. Each of these macro components and the policy trends that they indicate will be dealt with in more detail.

\section{Economic and job growth}

In most of the reviewed policy documents, slow economic growth and its accompanying lack of job growth are seen as the greatest contributing factor to the high levels of poverty in the country (e.g. NPC, 2012:24). A threefold process to address this issue is implied. First and foremost is to implement structural changes to stimulate formal economic growth to such an extent that it would "automatically" create more employment opportunities (NT, 2013a:iii). The second is to utilise education to enhance the capabilities of (especially young) people to become part of the formal economy and, thirdly, to create mechanisms and incentives to assist the unemployed to access the labour market (NPC, 2012:24; NT, 2013a:iii).

A noteworthy policy trend is the overt emphasis on the formal economy [IP3.1.1]. In this context investment in the "social wage" and especially education and skills development are seen as an important mechanism through which people could be enabled to become part of the economy. The same principle applies to public employment programmes (e.g. the expanded public works programme) which is intended to "provide a bridge between social grants and the sustainable employment envisaged in the New Growth Path, creating a mechanism that allows unemployed people to become a productive part of the economy while the structural changes required to create sustainable employment take effect" (NDP, 2012:280). These and other statements indicate that much of the social development efforts covered in the policy documents are viewed as stopgap mechanisms [IP3.1.2] that should be in place until growth in the formal economy can take effect (NPC, 2012:355) [IP3.1.1].

A second trend is a stronger focus on the creation of mechanisms that would require less government financial support and rely more on the direct contributions of the citizens involved. In the 2013 Budget (NT, 2013a:82,91) it is somewhat vaguely formulated as "contributory social security". More details on what is envisaged would probably emerge once the DSD's Consolidated Government Document on Social Security and Retirement Reform (DSD, 2012a:7) becomes known. If the guidelines of the NDP (NPC, 2012:53,73,359-361) are taken into account, however, it would involve greater (subsidised) access of low-paid workers to the social insurance schemes. This would represent a much stronger "individualist capitalist" approach [IP3.1.1], where the onus is on individuals to create their own "safety net".

\section{Improvement of the capabilities of individuals}

The NDP indicated a number of capabilities that should be improved. These ranged from the economy to infrastructure and from a sustainable environment to spatial development (NPC, 2012:44). One dealt with human capabilities. It included education, health, social protection and community safety (NPC, 2012:44). 
The NDP singled out formal education as the most important instrument through which the capabilities of individuals to become part of the economy could be improved (NPC, 2012:38,48-51) [SDP3.1.1]. It also indicated a number of other measures that should be used to support this education goal. These include early childhood development (ECD) programmes, the school meals and other nutrition programmes, as well as envisaged improvements in the school system, further education and training (FET), higher education, healthcare and social protection (NPC, 2012:44,48-53).

It is important to note that the Commission did not see the Expanded Public Works Programme (EPWP) as part of the education or employability improvement drive. In this regard it states, "In the initial stages it was assumed that the Expanded Public Works Programme (EPWP) would have a training component to enhance the employability of the participants and help them move on to a full-time job. However, it is now accepted that it is difficult to provide training through such programmes" (NPC, 2012:280). The EPWP now has a social protection [IP4.1] instead of a social development [SDP4.2] function. In this regard the Commission states, "EPWP should be targeted at low-skilled adults who are unemployed - the programme serves as unemployment assistance and protects this group from the risk associated with job losses or long-term unemployment" (NPC, 2012:382).

It is also important to note that the NDP does not allocate any direct capacitating or participatory development responsibility to so-called community development workers (CDWs) or practitioners (CDPs). Their function is basically viewed as the facilitation of the engagement of local government representatives with local "community organisations, housing associations or business associations" (NPC, 2012:438). A study conducted by Gray and Mubangizi (2010:186-197) found that it is unlikely that CDWs would succeed in performing this function, as well as various others. Given this result, it is uncertain exactly what the DSD wishes to achieve with its intended professionalisation of community or social development work (DSD, 2012:98) [SDP3.1.2]. It should also be noted that even the Parliamentary Committee on Social Development (PMG, 2013a) found the distinction between community development workers (CDWs) and community development practitioners (CDPs) confusing and came to the conclusion that there is a need to harmonise their activities "so that they could do joint work".

\section{Protection of the most vulnerable members of society}

The Commission describes its approach to social protection as a "hybrid" between an economic growth/inclusion model and the "Western industrial model" (NPC, 2012:355) and, in the latter regard, that the protection of the most vulnerable members of society [IP4.1] can best be improved through improvements to the social welfare system (NPC, 2012:376) [IP3.1.2]. They were of the opinion that the "current social welfare system needs to be reformed to deliver better results for vulnerable groups" (NPC, 2012:376) [SDP3.1.2] and recommended that the current "state-civil society model for delivering welfare services" should be reorganised in order to "ensure greater accountability, improve service delivery and protect the very vulnerable from neglect, exploitation and 
abuse" (NPC, 2012:377). The proposal that the welfare system should be reformed was also echoed elsewhere in the plan (NPC, 2012:72-73).

The NPC made the following three core recommendations on how the service delivery system could be improved.

- The first was that the state should play a much greater role in the provision of social welfare services (NPC, 2012:377). In this regard the NPC came to the conclusion that the "current model of shifting the burden of care, treatment and rehabilitation to the non-governmental sector and the poorest communities is not working" and that the "scale of social fragmentation and loss of purpose requires more systematic engagement with both governmental and non-governmental social service providers" (NPC, 2012:378).

- The second recommendation was that the skills deficit in the social welfare sector should be addressed. The NPC estimated that the country requires close to 55000 social service professionals (i.e. social workers, auxiliary social workers, community development workers, and child and youth care workers) in order to respond to the country's social welfare needs (NPC, 2012:377). Although the exact nature of the deficit is not specified, Chapter 13 of the NDP provides broad recommendations on how it should be addressed (NPC, 2012:325,407-443).

- The third core recommendation was that the current social security system should be expanded and strengthened to ensure that vulnerable groups and citizens are protected from the worst effects of poverty (NPC, 2012:378-379) [IP3.1.2].

\section{Conclusions regarding the new macro policy approach}

The analysis of the macro policy approach as advocated by the NPC indicated a marked shift away from the approach espoused in the RDP and White Paper on Social Welfare and, to a lesser degree, GEAR. Faith is now placed in the ability of the formal economy to create employment opportunities and, in the process, eliminate poverty [IP3.1.1]. Education is seen as the most important "ticket" that would give individuals access to these opportunities, while an effective welfare and social security system would have to be created to provide a safety net for those individuals and groups who cannot make use of these opportunities [IP3.1.2 \& IP4.1]. If this analysis is correct, it would, among other things, imply that the NPC has adopted a de facto institutional approach to welfare.

\section{Variables 4 and 5: Assumptions regarding the goal and function of social welfare}

In identifying policy trends in social welfare, it should first be noted that grants can either be seen as part of a social safety net and, therefore, representative of an institutional perspective [IP4.1], or as a redistribution instrument and part of the social development approach [SDP4.1]. It is, secondly, important to note that the NPC categorises early childhood development (ECD) programmes as a core part of education. The allocation of this function to the DSD is because it is primarily responsible for the Children's Act in terms of which ECD programmes are registered and monitored (Act 38 of 2005: sections 94 and 95). 
Although the policy documents still mention the redistributive role of welfare [SDP4.1], much stronger emphasis is placed on its function as a safety net and a remedial instrument (NPC, 2012:378) [IP4.1]. Some of the more detailed recommendations on how the system can be transformed and improved include the following:

- The introduction of a number of programmes and mechanisms aimed at the improvement of the quality and relevance of services rendered by the national and provincial departments of social development;

- A review of the financial awards policy and costing models for social welfare services and the improvement of mechanisms aimed at the monitoring of services rendered by the NGO sector. It includes:

- increased spending on subsidising NGOs;

- standardising the approach followed in the funding of NGOs; and

- the possible establishment of a regulatory body for non-profit organisations [IP3.1.2].

- The intensification of attempts to bridge the skills deficit in the social welfare sector through:

- increased spending on the training of social workers; and

- increasing the number of social service professionals to 55,000 (NPC, 2012:53) [IP3.1.2].

- The expansion and strengthening of the current social security system to provide a more appropriate "social safety net" (NPC, 2012:117,358-361) for vulnerable individuals and groups. This includes:

- social assistance support for orphaned children cared for by relatives;

- the development of a support package for unemployed youths; and

- a comprehensive household food security and nutrition strategy [IP3.1.2 \& IP4.1].

Although the NDP's overwhelming focus is on the safety net and remedial role of social welfare, its function of "empowering individuals to seize opportunities for decent employment and entrepreneurship" (NPC, 2012:382) [SDP4.2], as well as the construct "developmental social welfare" (NPC, 2012:356,361) [SDP4.2], are still mentioned, albeit briefly. In this regard the NPC formulates, somewhat vaguely, its view of the nature of the "developmental approach to social welfare provision" as follows: "This approach incorporates raising community awareness of social concerns and introducing strategies to reduce and prevent social pathologies" (NPC, 2012:361). This formulation has strong institutional overtones [IP4.1].

It may be concluded from the analysis that, in terms of the NDP, the primary functions of social welfare are to provide remedial and supportive services and a safety net for the vulnerable members of society [IP4.1]. This is strongly representative of the institutional perspective. The function of welfare as a social development instrument received scant attention. The overall impression was that the Commission thought that it could only play a secondary role. 


\section{Variables 6 and 7: Target systems and change strategy}

The NDP contains a number of indications on who should be targeted by the social protection safety net. They are summarised as "those who are not gainfully employed due to their vulnerable status, i.e. children, people with disabilities and the aged, as well as those who experience labour market vulnerability due to the nature of their jobs, low income levels or unemployment" (NPC, 2012:354). This description is typical of an institutional approach [IP3.1.2, IP4.1 \& IP6.3].

The Commission recommended that a "social minimum" or "social floor" should be determined by government and its "social partners" (NPC, 2012:73). This will entail determining the "minimum standard of living below which no one should fall" (NPC, 2012:73,355). Their proposed strategy is to utilise transfers in cash and in kind to provide a minimum income and essential basic services (e.g. water, electricity, sanitation, health care and education) to citizens who fall below this "social floor" (NPC, 2012:357-358) [IP7.1]. Although business and civil society initiatives should help citizen to function above the social floor, the "state will continue to bear primary responsibility for ensuring (that) this vision is achieved" (NPC, 2012:363).

From the analysis of the target systems and strategy proposed by the NPC, it may be concluded that its "hybrid model" (NPC, 2012:355) tends, at least initially, to lean strongly in the direction of a welfare state proposal [IP5.1]. The NPC's view that South Africa is currently in "a low growth, middle income trap" (NPC, 2012:110) implies that it would take time before job growth would lift significant numbers of citizens above the "social floor".

\section{Variables 8 and 9: Primary agents of social change and domain of practice}

The NPC is unequivocal in its view that a coalition between the state and civil society should function as the primary agent(s) of social change (NPC, 2012:376) [IP8.1]. They were also of the opinion that "complex social problems require professional interventions to deal with the symptoms and underlying causes of social pressures" (NPC, 2012:378) [IP7.1 and IP9.1]. This view, coupled with a call for an increase in the number of social workers and social auxiliary workers, would indicate that the NPC also saw these professionals and paraprofessionals as primary change agents [IP8.2]. The Commission was furthermore relatively explicit in its views on what the social welfare domain of practice [IP9.1] of the state-civil society coalition of service providers should entail (NPC, 2012:352-383).

The NPC also emphasised the importance of "the people" and government working cooperatively in bringing about improvement in all the fields covered by the NDP (NPC, 2012:1,37,479) [SDP8.1]. These fields, which range from the economy to human settlements, and from safety to social protection, may be viewed as the Commission's conceptualisation of the broad domain of social development practice [SDP9.1]. Participatory social development [SDP3.1.2] and community development workers/practitioners [SDP8.2] were given only a somewhat minor role to play only in the social protection field (NPC, 2012:377,438). 


\section{Variable 10: Pressures for social change}

Throughout its report the NPC highlighted a large number of factors that drive the need for social change. Apart from the two primary factors, i.e. unacceptably high levels of poverty and inequality, it included all those covered by the Diagnostic Report (NPC, 2011) such as youth unemployment and social fragmentation, as well as many others. An analysis of these factors indicated that they covered all the types of pressures that play a role in both the institutional and social development perspectives [IP10 and SDP10].

\section{MAIN CONCLUSIONS AND THEIR IMPLICATIONS}

The main conclusion that could be drawn from the analysis of the NDP and its associated policy documents is that they represent a marked shift in policy. This applies particularly to the perceived role and function of the economy/job creation and of social welfare/security.

The NPC categorises its approach to the elimination of poverty and the reduction of inequality as a "hybrid between economic growth/inclusion and the Western industrial model" (NPC, 2012:355). Although typical social development terminology is used to substantiate the Commission's approach, their planned route to poverty eradication is typical of an institutional perspective. This basically boils down to the stimulation of formal economic and job growth coupled to a safety net for those who do not have the "capability" to make use of the new opportunities. It can, therefore, be concluded that the Commission's approach does not in essence differ from the "Western industrial model" and that it already exhibits a number of the characteristics of a welfare state approach.

The Commission's planned route also revealed marked shifts in focus as far as the role and function of social welfare are concerned. Only three of the most relevant trends will be highlighted.

The NPC, in so many words, accused the government's developmental social welfare services of reneging on their responsibility by shifting the burden of care, treatment and rehabilitation to the non-governmental sector. It clearly states that the current system needs to be reformed in order to deliver better results (NPC, 2012:376). The focus of these reforms include the following:

- the state should take primary responsibility for some of the services that it had "outsourced";

- the NGO sector should be better subsidised;

- the skills deficit in the social welfare sector (including the lack of social workers) should be addressed; and

- the social security system should be extended.

Nearly all of the envisaged reforms are typical of an institutional approach. 
It was clear, secondly, that the Commission downplayed the potential contribution of participatory social development and community development workers/practitioners. It allocated only a small empowerment role to participatory development and positioned it squarely within the social protection field. The role of the community development worker was primarily limited to that of a facilitator in the interactions between local authorities and community leaders. Both trends represent a shift away from roles that were originally envisaged by the White Paper and the subsequent policy documents based on it.

It was clear, thirdly, that some of the provisions originally intended to function as social development "instruments" have lost or are losing this function. The Expanded Public Works Programme, for example, is no longer seen as an educational or employability improvement instrument, but simply as another social protection mechanism. The functions of the National Development Agency, which was originally touted as the instrument through which "sustainable community-driven" and "employment and income-creation" projects would be undertaken nationwide, are currently under review because they are not "sufficiently focused". There is also a marked decrease in the funding it receives. It can be expected that some of the other smaller "instruments" would follow this same route as and when the guidelines contained in the NDP are converted into practice.

If all the available evidence is taken into account, it has to be concluded that developmental social welfare is (apart from the rhetoric and macro policy statements) no longer the de facto local approach. It has already been replaced to a large extent by an institutional/welfare state approach/perspective. All indications are that this approach will grow in strength as the guidelines of the NDP are converted into practice. It is, consequently, imperative that all social workers should take cognisance of the new factors that will shape their practice in future.

\section{Acknowledgement}

The author wishes to thank Delport \& Co, a firm of auditors, for their expert assistance in the analysis of budgets and financial statements. Because of the rapidly changing policy scene, all data contained in this manuscript are applicable only up to 1/5/2013.

\section{REFERENCES}

ACTS (of law) see REPUBLIC OF SOUTH AFRICA.

AFRICAN NATIONAL CONGRESS (ANC). 1994. The Reconstruction and Development Programme: a policy framework. Johannesburg: Umanyano Publications.

DEPARTMENT OF SOCIAL DEVELOPMENT. 2012a. Annual Report for the year ended 31 March 2012. Pretoria: Department of Social Development.

DEPARTMENT OF SOCIAL DEVELOPMENT. 2012b. White Paper on Families in South Africa (Draft). [Online] Available: http://www.dsd.gov.za/ [Accessed: 12/04/2013].

\section{DSD see DEPARTMENT OF SOCIAL DEVELOPMENT.}


DU PLESSIS, C. 2013. Numsa threatens mass action over NDP (City Press: 7 March 2013). [Online] Available: http://www.citypress.co.za/politics/numsa-threatens-massaction-over-ndp/ [Accessed: 17/04/2013].

ESPING-ANDERSEN, G. 1990. The three worlds of welfare capitalism. Princeton: Princeton University Press.

ESTES, R.J. 1998. Developmental social work: a new paradigm for a new century. Paper presented at the $10^{\text {th }}$ International Symposium of the Inter-University Consortium for International Social Development (IUCISD), Cairo, Egypt, 28 June - 2 July 1998.

GONÇALVES, T.N.R., GOMES, E.X., ALVES, M.G. \& AZEVEDO, N.R. 2012. Theory and texts of educational policy: possibilities and constraints. Studies in Philosophy and Education, 31:275-288.

GORDHAN, P. 2013. Budget Speech: 2013. Pretoria: Republic of South Africa, National Treasury. RP: 345/2012.

GRAY, M. \& MUBANGIZI, B. 2010. Caught in the vortex: can local government community development workers in South Africa succeed? Community Development Journal, 45(2):186-197.

HYMAN, P. 2001. Social wage. In: O'HARA, P.A. (ed) Encyclopaedia of Political Economy: Volume 2 L-Z. London: Routledge, 582-585.

INDEX MUNDI. 2013. South Africa population below poverty line. [Online] Available: http://www.indexmundi.com/south_africa/population_below_poverty_line. html. [Accessed: 02/05/2013].

KIRST-ASHMAN, K.K. 2007. Introduction to social work and social welfare $\left(2^{\text {nd }}\right.$ ed). Belmont (CA): Thomson.

LAMMERS, W.J. \& BADIA, P. 2005. Fundamentals of behavioral research. Belmont: Thomson Wadsworth.

LAUBSCHER, J. 2013. Will this time be different? (SANLAM Economic Commentary). [Online] Available: http://www.sanlam.co.za/wps/wcm/connect/ Sanlam_EN/sanlam/investor+relations/economic+information/economic+commentary/w ill+this+time+be+different. [Accessed: 07/05/2013].

LOMBARD, A. 2008. The implementation of the White Paper for Social Welfare: a tenyear review. The Social Work Practitioner-Researcher, 20(2):154-173.

MAIL \& GUARDIAN. 2010. SA the biggest welfare state in the world, says economist. [Online] Available: http://mg.co.za/print/2010-02-18-sa-the-biggest-welfarestate-in-world. [Accessed: 01/06/2013].

MANUAL, T. 2012. NDP Launch Speech by Trevor A. Manuel, Minister in The Presidency: National Planning Commission. [Online] Available: http://www. thepresidency.gov.za/pebble.asp?relid=6601. [Accessed: 17/04/2013].

MAY, J. 2004. Poverty, social policy and the social wage. Paper presented at a Conference on "The Politics of Socio-Economic Rights in South Africa: 10 Years after 
Apartheid", 8 to 9 June 2004, Oslo, Norway. [Online] Available: http://www.sarpn.org/ [Accessed: 03/04/2013].

MIDGLEY, J. \& CONLEY, A. 2010. Social work and social development: theories and skills for developmental social work. Oxford: Oxford University Press.

MINISTRY IN THE OFFICE OF THE PRESIDENT. 1994. White Paper on Reconstruction and Development. Government Gazette, 353, no. 16085 (15 November). Pretoria: Government Printer.

MINISTRY OF WELFARE AND POPULATION DEVELOPMENT. 1997. White Paper for Social Welfare. Pretoria: Government Printers.

MWPD see MINISTRY OF WELFARE AND POPULATION DEVELOPMENT.

NATIONAL PLANNING COMMISSION. 2011. Diagnostic report. Pretoria: Department: The Presidency, National Planning Commission.

NATIONAL PLANNING COMMISSION. 2012. National Development Plan 2030: our future - make it work. Pretoria: Department: The Presidency, National Planning Commission.

NATIONAL TREASURY \& SOUTH AFRICAN REVENUE SERVICE. 2013. People's guide: Budget 2013. Pretoria: National Treasury.

NATIONAL TREASURY. 2013a. 2013 Budget review. Pretoria: National Treasury. RP: 344/2012.

NATIONAL TREASURY. 2013b. Vote 19: Social Development. Pretoria: National Treasury. RP: 343/2012.

NOYOO, N. 2006. Civil society and poverty reduction in South Africa. [Online] Available: http://www.sarpn.org/documents/d0002086/ [Accessed: 21/05/2013].

NPC see NATIONAL PLANNING COMMISSION.

NT \& SARS see NATIONAL TREASURY \& SOUTH AFRICAN REVENUE SERVICE.

NT see NATIONAL TREASURY.

O'HARA, P.A. (ed). 2001. Encyclopaedia of Political Economy: Volume 2 L-Z. London: Routledge.

OOSTHUIZEN, M. 2008. Estimating poverty lines for South Africa. Cape Town: Development Policy Research Unit, UCT.

PARLIAMENTARY MONITORING GROUP. 2013a. Department of Social Development and South African Social Security Agency Strategic Plans 2013 (Minutes of meeting held on 7 May 2013). Available: http://www.pmg. org.za/report/ 20130507-department-social-development-and-south-african-social-security-agencystrategic-plans-2013. [Accessed: 08/05/2013].

PARLIAMENTARY MONITORING GROUP. 2013b. Department of Social Development on its Strategic Plan 2013 (Minutes of meeting held on 23 Apr 2013). [Online] Available: http://www.pmg.org.za/report/20130423-department-social-development-its-strategic-plan-2013. [Accessed: 08/05/2013]. 
PATEL, L. 2005. Social welfare \& social development in South Africa. Cape Town: Oxford University Press Southern Africa.

PMG see PARLIAMENTARY MONITORING GROUP.

RANKIN, K. 1996. The social wage as a definitive component of political parties' philosophies. [Online] Available: http://keithrankin.co.nz/krnknsocw_wp.html [Accessed: 04/03/2013].

RDP see MINISTRY IN THE OFFICE OF THE PRESIDENT.

REPUBLIC OF SOUTH AFRICA. 1995. Children's Act (Act 38 of 2005) (As amended). Pretoria: Government Printer.

REPUBLIC OF SOUTH AFRICA. 1996. Constitution of the Republic of South Africa Act (Act 108 of 1996). Pretoria: Government Printer.

ROTHMAN, J. 1995. Approaches to community intervention. In: ROTHMAN, J., ERLICH, J.L. \& TROPMAN, J.E. (eds) Strategies of community intervention. Itasca: F.E. Peacock.

SHEAFOR, B.W., HOREJSI, C.R. \& HOREJSI, G.A. 1997. Techniques and guidelines for social work practice. Boston: Allyn and Bacon.

THERON, F. 2008. The development change agent - a micro-level approach to development. Pretoria: Van Schaik Publishers.

UNITED NATIONS RESEARCH INSTITUTE FOR SOCIAL DEVELOPMENT. 2010. Combating poverty and inequality: structural change, social policy and politics. Geneva: UNRISD.

\section{UNRISD see UNITED NATIONS RESEARCH INSTITUTE FOR SOCIAL DEVELOPMENT.}

WEYERS, M.L. 2011. The theory and practice of community work: a Southern African perspective. Potchefstroom: Keurkopie.

WORLD BANK. 2001. Social protection sector strategy: from safety net to springboard. Washington: The International Bank for Reconstruction and Development/The World Bank.

WORLD BANK. 2011. South Africa at a glance. [Online] Available: http://www. worldbank.org/en/country/southafrica. [Accessed: 07/05/2013].

ZASTROW, C. 2014. Introduction to social work and social welfare: empowering people $\left(11^{\text {th }}\right.$ ed). Belmont: Brooks/Cole.

ZUMA, J. 2012. Address by President Jacob Zuma on the occasion of the handover of the National Development Plan during the Joint Sitting of the National Assembly and the National Council of Provinces, Cape Town. [Online] Available: http://www.thepresidency.gov.za/pebble. asp?relid=6603 [Accessed: 17/04//2013].

Prof Mike Weyers, School of Psychosocial Behavioural Sciences: Social Work Division, North-West University: Potchefstroom Campus, South Africa. 